\title{
PENGARUH KOMITMEN ORGANISASI DAN KOMPETENSI AUDITOR TERHADAP KINERJA AUDITOR PADA KANTOR INSPEKTORAT DAERAH PROVINSI LAMPUNG
}

(Study Kasus pada Kantor Inspektorat Daerah Provinsi Lampung)

\author{
Herry Goenawan Soedarsa , Universitas Bandar Lampung \\ Anniza Ratu Mahlinda , Universitas Bandar Lampung \\ Riswan, Universitas Bandar Lampung
}

\begin{abstract}
Abtract
The main objective of this study was to determine the effect of organizational commitment and competence of the auditors on the performance of auditors Regional Inspectorate Office of Lampung Province.

Based on the analysis results, indicate that organizational commitment and competence of auditors have an influence on the performance of auditors. Based on the analysis results, the authors recommend the need to increase the love of organizations comply with regulations such as leadership, doing work optimally for the organization, and willing to sacrifice for the sake of the organization, even in a very urgent situation auditor must always exist for increased auditor competence organisasi.Perlu especially in works. Experience and knowledge of the auditor shall be increased by way of response to the environment of auditors and senior auditors others outside the organization. And seminars related to the auditor's work in order to increase knowledge and experience for the auditor. Because competent auditor is needed in the most important is organisasi.Yang should improve the performance of auditors in the audit team's work in the form of value the opinion of a teammate, not to be selfish, to be responsible, honest, obedient to the organization's rules, and loyal to the organization .

Head of the Office of Lampung Province Inspectorate through Kasub. Personnel should be more assertive attention to the performance of the auditor and the auditor should follow the trainings and seminars to increase knowledge and experience related to the auditor's work.
\end{abstract}

Keywords : Organizational Commitment, Auditor Performance, Offices Inspectorate Lampung

\section{LATAR BELAKANG}

Pada era Globalisasi, pesatnya pembangunan disegala bidang dengan pembiayaan dana pembangunan yang semakin meningkat, tentunya membawa dampak semakin kompleks \& rumitnya pengawasan terhadap keuangan negara dari berbagai penyimpangan \& penyalahgunaan anggaran.

Auditing adalah profesi yang bertugas untuk melayani kepentingan masyarakat yaitu dengan melaksanakan audit atas laporan keuangan sehingga dapat dimanfaatkan sebagai dasar pengambilan keputusan. Dalam tugasnya memeriksa laporan keuangan, auditor dituntut 
untuk bersikap profesional yang akan memberikan pendapatnya sesuai dengan kenyataan yang ditemuinya selama audit berlangsung.

Seorang auditor sebagai penyedia laporan keuangan auditan dalam melaksanakan audit tidak semata-mata hanya untuk kepentingan kliennya, melainkan juga untuk pihak lain yang berkepentingan terhadap laporan keuangan auditan. Profesi auditor mendapat kewajaran laporan keuangan yang disajikan kliennya. Untuk dapat mempertahankan kepercayaan dari klien dan dari para pemakai laporan keuangan auditan lainnya maka auditor dituntut menjadi seorang ahli.

Seorang auditor yang ahli tentunya harus mempunyai komitmen dalam berorganisasi dan kompetensi dalam bekerja. Tanggung jawab dan kejujuran sangat penting untuk menjadi komitmen seseorang dalam bekerja. Selain itu kedisplinan dan dan pengetahuan tidak kalah pentingnya dengan tanggung jawab dan kejujuran seseorang dalam bekerja. Dengan adanya kedisiplinan, tanggung jawab, dan kejujuran, serta pengetahuan yang baik, setidaknya sudah menunjukkan suatu kinerja yang baik.

Kinerja yang baik sangat diperlukan dalam bekerja. Kinerja dalam suatu departemen sebagai alat ukur atau tolak ukur suatu pekerjaan.

\section{TELAAH LITERATUR DAN PENGEMBANGAN HIPOTENSI}

\subsection{Kerangka Pemikiran}

a. Hubungan Komitmen Organisasi Terhadap Kinerja Auditor

Komitmen organisasi adalah sebagai suatu keadaan dimana seseorang karyawan memihak organisasi tertentu serta tujuan dan keinginannya untuk mempertahankan keanggotaannya dalam organisasi tersebut.

Kinerja auditor merupakan suatu hasil kerja secara kualitas yang dicapai oleh seorang auditor dalam melaksanakan tugasnya sesuai dengan tugas yang dibebankan kepadanya. Jadi dapat disimpulkan bahwa semakin besar keinginan seorang auditor untuk mencapai tujuan audit yang maksimal maka semakin baik pula kinerja yang akan diberikan seorang auditor terutama tanggung jawab dan kesetiaan auditor terhadap organisasi.

\section{b. Hubungan Kompetensi Auditor Terhadap Kinerja Auditor}

Kompetensi auditor adalah kecakapan auditor yang memadai untuk melakukan suatu tugas atau memiliki keterampilan dan kecakapan yang disyaratkan dalam bidang auditing. Kompetensi auditor adalah pengalaman dan pengetahuan.

Kinerja auditor merupakan suatu hasil kerja secara kualitas yang dicapai oleh seorang auditor dalam melaksanakan tugasnya sesuai dengan tugas yang dibebankan kepadanya. Oleh karena itu dapat dipahami bahwa seorang auditor yang memiliki pengetahuan dan pengalaman yang memadai akan lebih memahami dan mengetahui berbagai masalah dalam lingkungan audit kliennya. Jadi dapat disimpulkan bahwa semakin baik kompetensi yang dimiliki auditor maka semakin baik pula kinerja yang diberikan oleh seorang auditor terutama pada hasil audit.

\section{c. Hubungan Komitmen Organisasi Dan Kompetensi Auditor Terhadap Kinerja Auditor}

Semakin tinggi keinginan seorang auditor untuk mencapai tujuan audit yang maksimal maka semakin baik pula kinerja yang akan diberikan seorang auditor terutama tanggung jawab dan kesetiaan auditor terhadap organisasi. 
Begitu pula dengan kompetensi auditor, semakin baik kompetensi yang dimiliki auditor maka semakin baik pula kinerja yang diberikan oleh seorang auditor terutama pada hasil audit.

\section{Gambar 1. Paradigma}

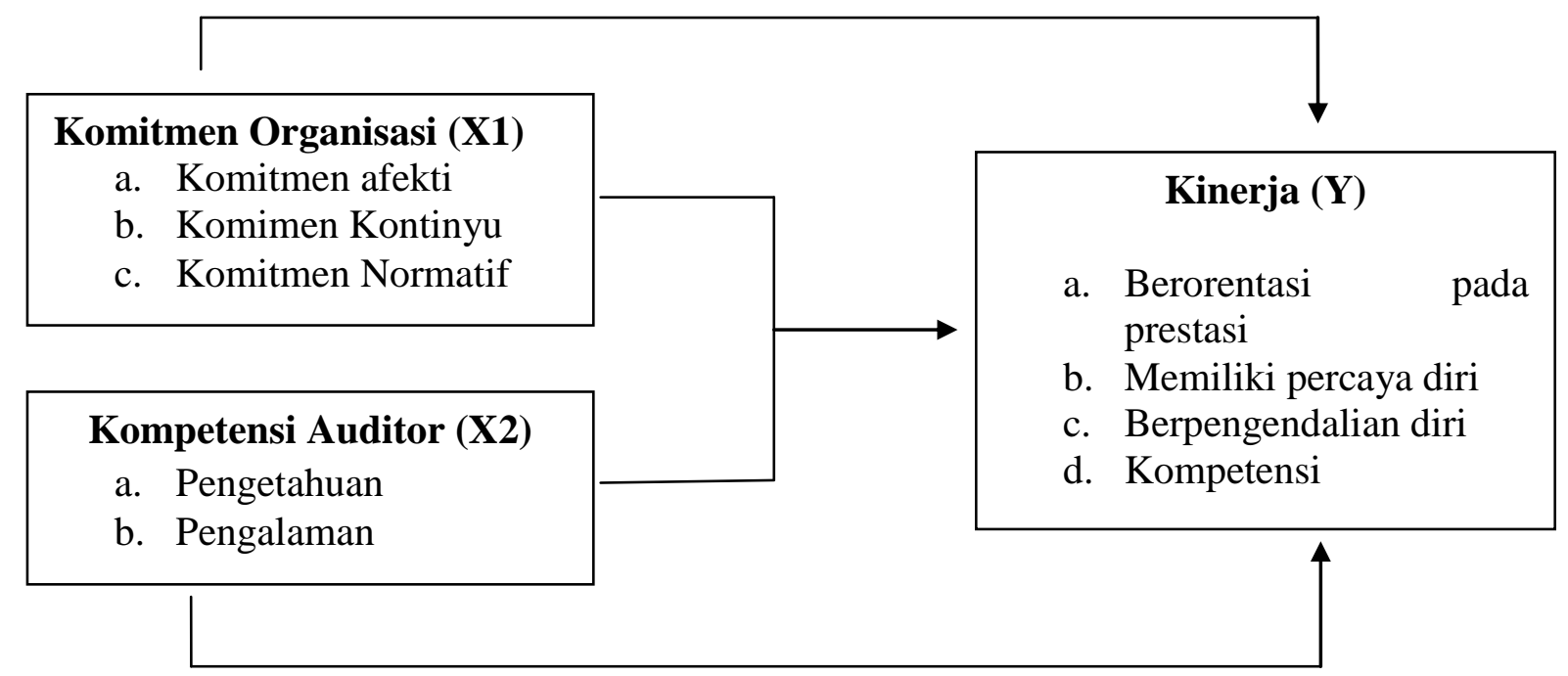

\section{METODOLOGI PENELITIAN}

\subsection{Obyek Penelitian}

Obyek penelitian dalam penelitian ini adalah auditor. Pada penelitian ini penulis melakukan penelitian pada auditor Kantor Inspektorat Daerah Provinsi Lampung. Dalam penelitian ini penulis melakukan penelitian dengan wawancara terstruktur (kuesioner) terhadap populasi auditor pada kantor inspektorat daerah provinsi lampung.

\section{Populasi}

Populasi adalah wilayah generalisasi yang terdiri atas obyek/subyek yang mempunyai kualitas karakteristik tertentu yang ditetapkan oleh peneliti untuk dipelajari dan kemudian ditarik kesimpulannya (sugiono, 2005:72). Adapun yang menjadi populasi dari penelitian ini adalah 45 orang auditor kantor Inspektorat Daerah Provinsi Lampung.

\section{Sampel}

Sampel yang akan diambil menurut Suharsimi Arikunto (1998:120) apabila objeknya $<100$ maka lebih baik diambil semuanya sehingga penelitiannya adalah penelitian populasi. Jika jumlah objeknya $>100$ dapat diambil $10-15 \%$ atau $20-25 \%$ atau lebih. Didalam penelitian ini peneliti mengambil seluruh responden yaitu 45 orang. Yang menjadi sampel dalam penelitian ini adalah 45 orang auditor kantor Inspektorat Daerah Provinsi Lampung.

\subsection{Operasional variable dan pengukuran}

\section{Operasional Variabel}

Berdasarkan judul skripsi yang diajukan yaitu "pengaruh komitmen organisasi dan kompetensi auditor terhadap kinerja auditor daerah provinsi Lampung". Beberapa variable yang akan diteliti hubungannya yaitu: 
a. Variabel Bebas (Independent Variable)

Variabel bebas adalah variabel yang mempengaruhi variabel lain yang tidak bebas. Dalam penelitian ini yang menjadi variabel bebasnya adalah "komitmen organisasi dan kompetensi auditor".

b. Variabel Terikat (Dependent Variable)

Variabel terikat adalah variabel yang dipengaruhi atau disebabkan oleh variabel lainnya.

Dalam penelitian ini yang menjadi variabel terikat adalah "kinerja auditor".

Untuk mengukur variabel komitmen organisasi dan kompetensi auditor, maka skala yang peneliti gunakan dalam penelitian ini adalah skala likert dimana menunjukkan tingkat efektivitas variabel yang diukur dengan 5 kategori sebagai berikut :
1. STS : Sangat Tidak Setuju
2. TS : Tidak Setuju
3. KS : Kurang Setuju
4. $\mathrm{S} \quad$ : Setuju
5. SS : Sangat Setuju

Skala ini mengukur tingkat kesetujuan atau ketidak setujuan auditor terhadap komitmen organisasi dan kompetensi auditor. Untuk mengukur kinerja auditor, kuesioner diisi oleh pimpinan karyawan. Tetap menggunakan skala Likert yang menunjukkan efektifitas variabel yang diukur dengan 5 kategori sebagai berikut :
1) STS : Sangat Tidak Setuju
2) TS : Tidak Setuju
3) KS : Kurang Setuju
4) $\mathrm{S} \quad$ : Setuju
5) SS : : Sangat Setuju

Skala ini mengukur tingkat kesetujuan dan ketidaksetujuan pimpinan terhadap serangkaian pertanyaan yang mengukur kinerja karyawan. Skala yang digunakan dalam penelitian ini adalah skala ordinal. Skala ordinal data hasil pengamatan diklasifikasikan ke dalam kategori-kategori, dan diantara kategori ada suatu urutan. Skala ordinal merupakan skala pengukuran yang sifatnya membedakan dan mengurutkan.

\section{Pengukuran}

\begin{tabular}{|l|l|c|c|}
\hline \multicolumn{1}{|c|}{ Analisis } & \multicolumn{1}{|c|}{ Devinisi } & Item & Skala \\
\hline Komitmen organisasi & Komitmen afektif & $1-3$ & Ordinal \\
& Komitmen kontinyu & $4-7$ & Ordinal \\
& Komitmen normatif & $8-10$ & Ordinal \\
& & & \\
\hline Kompetensi auditor & Pengetahuan Pengetahuan tentang audit & $11-13$ & Ordinal \\
& Pengetahuantentang prinsip akuntansi. & $14-15$ & Ordinal \\
& Pengalaman Mendeteksi kesalahan & $16-18$ & Ordinal \\
& Lama melakukan audit & $19-20$ & Ordinal \\
& & & \\
\hline Kinerja auditor & Berorientasi pada prestasi & $21-22$ & Ordinal \\
& Memiliki percaya diri & $23-24$ & Ordinal \\
& Berperngendalian diri Kompetensi & $25-27$ & Ordinal \\
& & & \\
\hline
\end{tabular}




\subsection{Metode Pengumpulan Data}

a. Penelitian Kepustakaan (Library Research)

Penelitian kepustakan adalah penelitian yang dilakukan untuk mengumpulkan data dan informasi melalui bahan-bahan keperpustakaan yang dijadikan landasan dan alat bagi praktek penelitian dilapangan. Dengan metode ini penulis menghimpun data dari berbagai literatur guna menunjang penulisan skripsi ini.

b. Penelitian Lapangan

Penulis menggunakan obyek penelitian auditor kantor Inspektorat daerah provinsi Lampung.

c. Pengumpulan data ini penulis lakukan dengan cara:

1. Kuesioner

Kuesioner adalah pertanyaan tertulis yang digunakan untuk memperoleh informasi dari responden dalam arti laporan tentang pribadinya atau hal-hal yang ia ketahui.

2. Wawancara (Interview)

Wawancara adalah cara untuk memperoleh informasi dengan bertanya secara langsung kepada objek atau yang diwawancarai.

\subsection{Metode Analisa Data}

Analisa data adalah cara-cara mengolah data yang telah terkumpul kemudian dapat memberikan interpretasi. Hasil pengolahan data dapat digunakan untuk menjawab masalah yang telah dirumuskan.

\section{Analisis Kualitatif}

Analisis kualitatif yaitu metode nilai kelayakan variabel-variabel penelitian dengan pedoman pada pengetahuan teoritis. Teknik ini digunakan untuk memberikan gambaran yang jelas mengenai masalah-masalah yang akan dibahas dengan menginterprestasikan variabelvariabel yang relevan.

\section{a. Skala Interval}

Skala interval merupakan salah satu teknik pengukuran yang dipergunakan untuk mengetahui tangapan responden terhadap variabel penelitian. Skala interval mempunyai kriteria penilaian 1-5. Dengan menggunakan rumus sebagai berikut :

I = Nilai Tertinggi - Nilai Terendah

\section{Kategori}

\section{b. Skala Likert}

Skala Likert adalah suatu skala psikometrik yang umum digunakan dalam kuesioner, dan merupakan skala yang paling banyak digunakan dalam riset berupa survei. Biasanya disediakan lima pilihan skala dengan format seperti:

Skala likert untuk mengetahui tanggapan responden terhadap masing- masing butir instrumen indikator. Kriteria penilaian sebagai berikut :

$\mathrm{I}=$ Skor Tertinggi - Skor Terendah 


\section{Analisis Kuantitatif}

Analisis kuantitatif yaitu menganalisis masalah dengan menggunakan rumus korelasi product moment untuk mengetahui hubungan komitmen organisasi dan kompetensi auditor terhadap kinerja auditor. Sedangkan koefisien penentu untuk menentukan besarnya pengaruh komitmen organisasi dan kompetensi auditor terhadap kinerja dan kemudian diuji dengan uji hipotesis.

\section{Regresi Linier Berganda}

Menurut sugiyono(2005:210) analisis regresi berganda digunakan untuk meramalkan keadaan (naik turunnya) variabel dependen. Bila dua atau lebih variabel independen sebagai faktor prediktor dimanipulasi (dinaik turunkan) nilainya. Jadi regresi linier berganda akan dilakukan bila jumlah variabel independennya minimal dua.

Rumus $=\mathrm{Y}=\mathrm{a}+\mathrm{b}_{1} \mathrm{x}_{1}+\mathrm{b}_{2} \mathrm{x}_{2}+\mathrm{e}$

$\mathrm{Y}=$ Subyek dalam variabel independen yaitu kinerja auditor

$\mathrm{a}=$ faktor yang mempengaruhi $\mathrm{Y}$ bila $\mathrm{X}=0$

$\mathrm{b}=$ angka arah/koefisien regresi, yang menunjukkan angka peningkatan/ penurunan variabel independen bila $b(+)$ maka naik, bila $b(-)$ maka turun.

$\mathrm{x}_{1}=$ objek dalam variabel independen yaitu komitmen organisasi

$\mathrm{x}_{2}=$ objek dalam variabel independen yaitu kompetensi auditor

$\mathrm{e}=$ error

\section{Uji Validitas dan Reliabilitas}

\section{Uji validitas}

Validitas adalah tingkat keandalah dan kesahihan alat ukur yang digunakan. Intrumen dikatakan valid berarti menunjukkan alat ukur yang dipergunakan untuk mendapatkan data itu valid atau dapat digunakan untuk mengukur apa yang seharusnya di ukur (Sugiyono, 2004:137). Dengan demikian, instrumen yang valid merupakan instrumen yang benar-benar tepat untuk mengukur apa yang hendak di ukur. Penggaris dinyatakan valid jika digunakan untuk mengukur panjang, namun tidak valid jika digunakan untuk mengukur berat. Artinya, penggaris memang tepat digunakan untuk mengukur panjang, namun menjadi tidak valid jika penggaris digunakan untuk mengukur berat.

Uji validitas berguna untuk mengetahui apakah ada pernyataan-pernyataan pada kuesioner yang harus dibuang/diganti karena dianggap tidak relevan. Teknik untuk mengukur validitas kuesioner adalah sebagai berikut dengan menghitung korelasi antar data pada masing-masing pernyataan dengan skor total, memakai rumus korelasi product moment, sebagai berikut :

$$
r=\frac{n\left(\sum X Y\right)-\sum X \sum Y}{\sqrt{\left[n \sum X^{2}-\left(\sum X\right)^{2}\right]\left[n \sum Y^{2}-\left(\sum Y\right)^{2}\right]}}
$$

Item Instrumen dianggap Valid jika lebih besar dari 0,3 atau bisa juga dengan membandingkannya dengan $r$ tabel. Jika $r$ hitung $>r$ tabel maka valid.

\section{Uji Reliabilitas}

Uji reliabilitas berguna untuk menetapkan apakah instrumen yang dalam hal ini kuesioner dapat digunakan lebih dari satu kali, paling tidak oleh responden yang sama akan menghasilkan data yang konsisten. Dengan kata lain, reliabilitas instrumen mencirikan 
tingkat konsistensi. Banyak rumus yang dapat digunakan untuk mengukur reliabilitas diantaranya adalah rumus Spearman Brown $r_{11 \frac{2 . r_{b}}{1+r_{b}}}$

\section{Keterangan :}

R 11 : adalah nilai reliabilitas

$\mathrm{R} \mathrm{b} \quad$ : adalah nilai koefisien korelasi

Nilai koefisien reliabilitas yang baik adalah diatas 0,7 (cukup baik), di atas 0,8 (baik).

\section{Pengujian Hipotesis}

\section{a. Secara Simultan}

\section{Kriteria pengujian hipotesis :}

Jika $\mathrm{f}_{\text {hitung }}>\mathrm{f}_{\text {tabel }}$ maka $\mathrm{H}_{\mathrm{o}}$ ditolak dan $\mathrm{H}_{\mathrm{a}}$ diterima

Jika $\mathrm{f}_{\text {hitung }}<\mathrm{f}_{\text {tabel }}$ maka $\mathrm{H}_{\mathrm{o}}$ diterima dan $\mathrm{H}_{\mathrm{a}}$ ditolak

$\mathbf{H}_{\mathbf{0}}=$ tidak terdapat pengaruh komitmen organisasi dan kompetensi auditor secara simultan terhadap kinerja auditor

$\mathbf{H}_{\mathbf{a}}=$ terdapat pengaruh komitmen organisasi dan kompetensi auditor secara simultan terhadap kinerja auditor

\section{b. Secara Parsial (uji t)}

Uji t digunakan untuk mengetahui hubungan masing-masing variabel bebas terhadap variabel terikat. Uji $t$ dilakukan dengan membandingkan antara $t_{\text {hitung }}$ dengan $t_{\text {tabel }}$.

\section{Kriteria Pengujian Hipotesis :}

Jika $t_{\text {hitung }}>t_{\text {tabel }}$ maka $\mathrm{H}_{\mathrm{o}}$ ditolak dan $\mathrm{H}_{\mathrm{a}}$ diterima

Jika $\mathrm{t}_{\text {hitung }}<\mathrm{t}_{\text {tabel }}$ maka $\mathrm{H}_{\mathrm{o}}$ diterima dan $\mathrm{H}_{\mathrm{a}}$ ditolak

$\mathbf{H}_{\mathbf{o}}=$ tidak terdapat pengaruh komitmen organisasi terhadap kinerja auditor

$\mathbf{H}_{\mathbf{a}}=$ terdapat pengaruh komitmen organisasi terhadap kinerja auditor

$\mathbf{H}_{\mathbf{0}}=$ tidak terdapat pengaruh kompetensi auditor terhadap kinerja auditor

$\mathbf{H}_{\mathbf{a}}=$ terdapat pengaruh kompetensi auditor terhadap kinerja auditor

\section{HASIL DAN PENELITIAN}

\subsection{Deskripsi Objek Penelitian}

Dalam penelitian ini yang menjadi objek penelitiannya adalah auditor di kantor Inspektorat Daerah Provinsi Lampung. Jumlah auditor dikantor Inspektorat Daerah Provinsi Lampung berjumlah 45 orang, maka penulis mengambil seluruh populasi auditor untuk penelitian ini. Kuesioner yang disebarkan sebanyak 45 kuesioner. Didapat informasi yang menyangkut demografi responden sebagai berikut :

a. Jenis kelamin

Dari hasil penyebaran kuesioner dengan 45 responden, diketahui bahwa 36 responden $(80 \%)$ adalah laki-laki dan sisanyasebanyak 9 responden (20\%) adalah perempuan.

b. Pendidikan

Dari hasil penyebaran kuesioner dengan 45 responden, diketahui bahwa 27 responden $(60 \%)$ berjenjang pendidikan Strata 1 (S1) dan $18(40 \%)$ responden berjenjang pendidikan Strata 2 (S2). 
c. Lama bekerja

Berdasarkan informasi yang diperoleh dari 45 responden, diketahui lamanya responden bekerja pada dinas yang bersangkutan sebanyak 9 responden (20\%) 1 -3 tahun, 18 responden (40\%) antara 3-5 tahun, 18 responden (40\%) diatas 5 tahun.

d. Usia

Berdasarkan informasi yang diperoleh dari 45 responden, diketahui bahwa 27 responden $(60 \%)$ berusia $30-40$ tahun, dan 18 responden $(40 \%)$ berusia $>40$ tahun.

Analisis Kualitatif

Hasil Tanggapan Responden Berdasarkan Deskripsi Frekuensi Jumlah Responden

Berdasarkan hasil pengolahan data tentang tanggapan responden terhadap variabel penelitian sebagai berikut :

I $=$ Nilai Tertinggi - Nilai Terendah

Hasil perhitungan interval dari nilai skor jawaban responden yang telah dikelompokkan dalam 5 kriteria. Uraian lebih jelasnya sebagai berikut :

a. Variabel Komitmen Organisasi

Tabel 2. Frekuensi Tentang Komitmen Organisasi $\left(\mathbf{X}_{1}\right)$ Berdasarkan Hasil Penyebaran Kuesioner Terhadap 25 Responden.

\begin{tabular}{|l|l|c|c|c|}
\hline No & \multicolumn{1}{|c|}{ Kategori } & Interval & Frekuensi & Persentase \\
\hline 1 & Sangat baik & $\mathbf{4 2 - 5 0}$ & $\mathbf{2 3}$ & $\mathbf{5 1 \%}$ \\
\hline 2 & Baik & $\mathbf{3 4 - 4 1}$ & $\mathbf{2 2}$ & $\mathbf{4 9 \%}$ \\
\hline 3 & Cukup baik & $\mathbf{2 6 - 3 3}$ & $\mathbf{0}$ & $\mathbf{0 \%}$ \\
\hline 4 & Kurang baik & $\mathbf{1 8 - 2 5}$ & $\mathbf{0}$ & $\mathbf{0 \%}$ \\
\hline $\mathbf{5}$ & Sangat kurang baik & $\mathbf{1 0 - 1 7}$ & $\mathbf{0}$ & $\mathbf{0 \%}$ \\
\hline \multicolumn{2}{|c|}{ Jumlah } & 45 & $\mathbf{1 0 0 \%}$ \\
\hline
\end{tabular}

Sumber : data diolah dari hasil kuesioner 2012

Dari tabel diatas dapat diketahui bahwa tanggapan responden terhadap komitmen organisasi sebanyak 22 responden (49\%) menyatakan memiliki komitmen organisasi yang baik, dan 23 responden (51\%) menyatakan memiliki komitmen organisasi yang sangat baik.

b. Variabel Kompetensi Auditor

Tabel 3. Frekuensi Tentang Kompetensi Auditor $\left(\mathbf{X}_{2}\right)$ Berdasarkan Hasil Penyebaran Kuesioner Terhadap 25 Responden.

\begin{tabular}{|l|l|c|c|c|}
\hline No & \multicolumn{1}{|c|}{ Kategori } & Interval & Frekuensi & Persentase \\
\hline 1 & Sangat baik & $\mathbf{4 2 - 5 0}$ & $\mathbf{1 3}$ & $\mathbf{2 9 \%}$ \\
\hline 2 & Baik & $\mathbf{3 4 - 4 1}$ & $\mathbf{2 7}$ & $\mathbf{6 0 \%}$ \\
\hline
\end{tabular}




\begin{tabular}{|l|l|c|c|c|}
\hline 3 & Cukup baik & $\mathbf{2 6 - 3 3}$ & $\mathbf{5}$ & $\mathbf{1 1 \%}$ \\
\hline 4 & Kurang baik & $\mathbf{1 8 - 2 5}$ & $\mathbf{0}$ & $\mathbf{0 \%}$ \\
\hline 5 & Sangat kurang baik & $10-17$ & 0 & $0 \%$ \\
\hline \multicolumn{2}{|c|}{ Jumlah } & 45 & $100 \%$ \\
\hline
\end{tabular}

Sumber : data diolah dari hasil kuesioner 2012

Dari tabel diatas diketahui bahwa tanggapan responden terhadap kompetensi auditor sebanyak 5 responden $(\mathbf{1 1 \%})$ menyatakan memiliki kompetensi auditor yang cukup baik, dan 27 responden $(60 \%)$ menyatakan memiliki kompetensi auditor yang baik, dan 13 responden (29\%) menyatakan memiliki kompetensi auditor yang sangat baik.

c. Variabel Kinerja Auditor

Tabel 4. Frekuensi Tentang Kinerja Auditor (Y) Berdasarkan Hasil Penyebaran Kuesioner Terhadap 25 Responden.

\begin{tabular}{|l|l|c|c|c|}
\hline No & \multicolumn{1}{|c|}{ Kategori } & Interval & Frekuensi & Persentase \\
\hline 1 & Sangat baik & $\mathbf{4 2 - 5 0}$ & $\mathbf{5}$ & $\mathbf{1 1 \%}$ \\
\hline $\mathbf{2}$ & Baik & $\mathbf{3 4 - 4 1}$ & $\mathbf{2 9}$ & $\mathbf{6 5 \%}$ \\
\hline $\mathbf{3}$ & Cukup baik & $\mathbf{2 6 - 3 3}$ & 11 & $\mathbf{2 4 \%}$ \\
\hline 4 & Kurang baik & $\mathbf{1 8 - 2 5}$ & $\mathbf{0}$ & $\mathbf{0 \%}$ \\
\hline $\mathbf{5}$ & Sangat kurang baik & 0 & $\mathbf{0 \%}$ \\
\hline \multicolumn{2}{|c|}{ Jumlah } & 45 & $\mathbf{1 0 0 \%}$ \\
\hline
\end{tabular}

Sumber : data diolah dari hasil kuesioner 2012

Dari tabel diatas dapat diketahui bahwa tanggapan responden terhadap kinerja auditor sebanyak 11 responden (24\%) menyatakan memiliki kinerja auditor yang cukup baik, 29 responden (65\%) menyatakan memiliki kinerja auditor yang baik, dan 5 responden $(11 \%)$ menyatakan memiliki kinerja auditor yang sangat baik.

\subsection{Hasil Tanggapan Responden Berdasarkan Score Jawaban Responden}

Berdasarkan hasil pengolahan data tentang tanggapan responden berdasarkan butir pertanyaaan berikut :

$$
\mathrm{I}=\mathrm{\text {SkorTertinggi } - \text { Skor Terendah }}
$$

a. Variabel Komitmen Organisasi $\left(\mathbf{X}_{1}\right)$

Tabel 5. Tanggapan Responden Terhadap Variabel Komitmen Organisasi Berdasarkan Item Pertanyaan.

\begin{tabular}{|c|c|c|c|c|}
\hline Item Pertanyaan & Skor Real & Skor Maximum & Persentase & Kategori \\
\hline Komitmen Afektif & & & & \\
\hline 1 & 184 & 225 & 82 & Baik \\
\hline 2 & 189 & 225 & 84 & Sangat Baik \\
\hline 3 & 176 & 225 & 78 & Baik \\
\hline Jumbh I & 549 & 675 & 81 & Baik \\
\hline
\end{tabular}




\begin{tabular}{|c|c|c|c|c|}
\hline Komitmen Kontinyu & & & & \\
\hline 4 & 184 & 225 & 82 & Baik \\
\hline 5 & 188 & 225 & 84 & Baik \\
\hline 6 & 180 & 225 & 80 & Baik \\
\hline 7 & 178 & 225 & 79 & Baik \\
\hline Jumlah II & 730 & 900 & 81 & Baik \\
\hline 8 & & & & \\
\hline 9 & 179 & 225 & 80 & Baik \\
\hline 10 & 184 & 225 & 82 & Baik \\
\hline Jumlah III & 183 & 225 & 81 & Baik \\
\hline Jumlah I+II+III & 1825 & 2250 & 81 & Baik \\
\hline
\end{tabular}

Berdasarkan tabel diatas, dapat disimpulkan komitmen organisasi auditor dapat dikategorikan cukup baik dengan skor pencapaian 1825 dari skor maksimum 2250 . Bila dilihat dari masing-masing indikator, komitmen afektif, komitmen kontinyu, dan komitmen normatif masing-masing mendapat kategori baik. Berarti didalam diri auditor telah memiliki komitmen afektif, komitmen kontinyu, dan komitmen normatif yang baik dari seorang auditor didalam menjalankan pekerjaannya.

\section{b. Variabel Kompetensi Auditor $\left(\mathbf{X}_{2}\right)$}

Tabel 6. Tanggapan Responden Terhadap Variabel Kompetensi Auditor Berdasarkan Item Pertanyaan.

\begin{tabular}{|c|c|c|c|c|}
\hline Item Pertanyaan & Skor Real & Skor Maximum & Persentase & Kategori \\
\hline Pengetahuan Tentang Audit & & & & \\
\hline 1 & 178 & 225 & 79 & Baik \\
\hline 2 & 174 & 225 & 77 & Baik \\
\hline $\begin{array}{c}\text { Pengetahuan Tentang Prinsip } \\
\text { Akuntansi }\end{array}$ & 352 & 450 & 78 & Baik \\
\hline 3 & & & & \\
\hline 4 & 178 & 225 & 79 & Baik \\
\hline 5 & 180 & 225 & 80 & Baik \\
\hline Jumlah II & 174 & 225 & 77 & Baik \\
\hline Mendeteksi Kesalahan & 532 & 675 & 79 & Baik \\
\hline 6 & 172 & 225 & 76 & Baik \\
\hline 7 & 172 & 225 & 76 & Baik \\
\hline 8 & 173 & 225 & 77 & Baik \\
\hline Jumlah III & 517 & 675 & 77 & Baik \\
\hline Lama Melakukan Audit & & & & \\
\hline 9 & 173 & 225 & 77 & Baik \\
\hline 10 & 175 & 225 & 78 & Baik \\
\hline Jumlah IV & 348 & 450 & 77 & Baik \\
\hline Jumlah I+II+III+IV & 1749 & 2250 & 78 & Baik \\
\hline
\end{tabular}


Berdasarkan tabel diatas, dapat disimpulkan kompetensi auditor dapat dikategorikan cukup baik dengan skor pencapaian 1749 dari skor maksimum 2250 . Bila dilihat dari masing-masing indikator, pengetahuan tentang audit, pengetahuan tentang prinsip akuntansi, mendeteksi kesalahan, dan lama melakukan audit masing-masing mendapat kategori baik. Berarti didalam diri auditor telah memiliki pengetahuan dan pengalaman yang baik dari seorang auditor didalam menjalankan pekerjaannya

\section{c. Variabel Kinerja Auditor}

Tabel 7. Tanggapan Responden Terhadap Variabel Kinerja Auditor Berdasarkan Item Pertanyaan.

\begin{tabular}{|c|c|c|c|c|}
\hline Item Pertanyaan & Skor Real & Skor Maximum & Persentase & Kategori \\
\hline Berorientasi Pada Prestasi & & & & \\
\hline 1 & 171 & 225 & 76 & Baik \\
\hline 2 & 169 & 225 & 75 & Baik \\
\hline Jumlah I & 340 & 450 & 76 & Baik \\
\hline Memiliki Percaya Diri & & & & \\
\hline 3 & 168 & 225 & 75 & Baik \\
\hline 4 & 172 & 225 & 76 & Baik \\
\hline Jumlah II & 340 & 450 & 76 & Baik \\
\hline Berpengendalian Diri & & & & \\
\hline 5 & 166 & 225 & 74 & Baik \\
\hline 6 & 170 & 225 & 76 & Baik \\
\hline 7 & 161 & 225 & 72 & Baik \\
\hline Jumlah III & 497 & 675 & 74 & Baik \\
\hline Kompetensi & & & & \\
\hline 8 & 165 & 225 & 73 & Baik \\
\hline 9 & 161 & 225 & 72 & Baik \\
\hline 10 & 162 & 225 & 72 & Baik \\
\hline Jumlah IV & 488 & 675 & 72 & Baik \\
\hline Jumlah I+II+III+IV & 1665 & 2250 & 74 & Baik \\
\hline
\end{tabular}

Berdasarkan tabel diatas, dapat disimpulkan kinerja auditor dapat dikategorikan cukup baik dengan skor pencapaian 1665 dari skor maksimum 2250 . Bila dilihat dari masing-masing indikator berorientasi pada prestasi, memiliki percaya diri, berpengendalian diri, dan kompetensi masing-masing mendapat kategori baik. Berarti didalam diri auditor telah memiliki kinerja auditor yang baik dari seorang auditor didalam menjalankan pekerjaannya.

\section{Analisis Kuantitatif}

\section{Analisis Regresi Linier Berganda}

Berdasarkan pengolahan data menggunakan program SPSS for Windows Version 18.0 sebagaimana terlampir, maka diperoleh hasil untuk analisis regresi sebagai berikut : 
Tabel 8. Tabel Coefficients

\begin{tabular}{|c|c|c|c|c|c|}
\hline \multirow{2}{*}{ Model } & \multicolumn{2}{|c|}{$\begin{array}{c}\text { Unstandardized } \\
\text { Coefficients }\end{array}$} & $\begin{array}{c}\text { Standardized } \\
\text { Coefficients }\end{array}$ & \multirow[t]{2}{*}{$\mathbf{t}$} & \multirow{2}{*}{ Sig. } \\
\hline & B & Std. Error & Beta & & \\
\hline 1 (Constant) & 2.412 & 3.670 & & .657 & .515 \\
\hline Komitmen & .418 & .207 & .404 & 2.025 & .049 \\
\hline kompetensi & .453 & .204 & .444 & 2.224 & .032 \\
\hline
\end{tabular}

a. Dependent Variable: kinerja

Sedangkan $R$ Square pada tabel Model Summary ${ }^{b}$ sebesar 0,684 yang dapat dilihat pada lampiran. Maka dari tabel diatas diperoleh bentuk persamaan Regresi Linier Berganda sebagai berikut:

$Y=\mathbf{2 , 4 1 2 + 0 , 4 1 8 X _ { 1 } + 0 , 4 5 3 X _ { 2 }}$

Penjelasan berdasarkan regresi linier berganda yang terbentuk sebagai berikut :

a. Koefisien regresi menunjukkan tanda positif (+) hal ini berarti ada suatu kondisi yang searah yaitu peningkatan variabel $X$ akan menyebabkan peningkatan variabel Y.

b. Koefisien regresi komitmen organisasi sebesar 0,418 menunjukkan berpengaruh positif dan signifikan, menunjukkan bahwa komitmen organisasi yang dimiliki seorang auditor akan berdampak pada peningkatan kinerja auditor atau jika komitmen organisasi meningkat sebesar $1 \%$ maka kinerja akan meningkat sebesar $42 \%$.

c. Koefisien regresi kompetensi auditor sebesar 0,453 menunjukkan berpengaruh positif dan signifikan, menunjukkan bahwa kompetensi auditor yang dimiliki seorang auditor akan berdampak pada peningkatan kinerja auditor atau jika kompetensi auditor meningkat sebesar $1 \%$ maka kinerja akan meningkat sebesar $45 \%$.

d. Koefisien determinasi ( $R$ Square) sebasar 0,684 menginformasikan bahwa variabel kinerja auditor dapat dijelaskan oleh kedua variabel independen dalam penelitian ini yakni komitmen organisasi dan kompetensi auditor sebesar $68 \%$ dan selebihnya yaitu $32 \%$, dijelaskan oleh faktor-faktor lain diluar penelitian penulis, seperti kecerdasan emosional, kecerdasan spiritual, dan kecerdasan intelektual yang dimiliki auditor dalam pekerjaannya.

\subsection{Uji Validitas dan Reliabilitas}

Rumus Uji Validitas adalah:

$$
r=\frac{n\left(\sum X Y\right)-\sum X \sum Y}{\sqrt{\left[n \sum X^{2}-\left(\sum X\right)^{2}\right]\left[n \sum Y^{2}-\left(\sum Y\right)^{2}\right]}}
$$

Tabel 9. Tabel Uji validitas

\begin{tabular}{|c|c|c|c|}
\hline Pernyataan & r hitung & r tabel & keterangan \\
\hline 1 & 0.730 & 0.288 & VALID \\
\hline 2 & 0.727 & 0.288 & VALID \\
\hline 3 & 0.488 & 0.288 & VALID \\
\hline 5 & 0.628 & 0.288 & VALID \\
\hline 6 & 0.441 & 0.288 & VALID \\
\hline 7 & 0.483 & 0.288 & VALID \\
\hline 8 & 0.292 & 0.288 & VALID \\
\hline
\end{tabular}




\begin{tabular}{|c|c|c|c|}
\hline 9 & 0.588 & 0.288 & VALID \\
\hline 10 & 0.587 & 0.288 & VALID \\
\hline 11 & 0.490 & 0.288 & VALID \\
\hline 12 & 0.628 & 0.288 & VALID \\
\hline 13 & 0.528 & 0.288 & VALID \\
\hline 14 & 0.413 & 0.288 & VALID \\
\hline 16 & 0.576 & 0.288 & VALID \\
\hline 17 & 0.549 & 0.288 & VALID \\
\hline 18 & 0.412 & 0.288 & VALID \\
\hline 19 & 0.530 & 0.288 & VALID \\
\hline 20 & 0.628 & 0.288 & VALID \\
\hline 21 & 0.513 & 0.288 & VALID \\
\hline 22 & 0.520 & 0.288 & VALID \\
\hline 23 & 0.595 & 0.288 & VALID \\
\hline 24 & 0.499 & 0.288 & VALID \\
\hline 25 & 0.428 & 0.288 & VALID \\
\hline 26 & 0.771 & 0.288 & VALID \\
\hline 27 & 0.602 & 0.288 & VALID \\
\hline 29 & 0.621 & 0.288 & VALID \\
\hline 30 & 0.524 & 0.288 & VALID \\
\hline & 0.584 & 0.288 & VALID \\
\hline
\end{tabular}

Berdasarkan hasil perhitungan dengan program SPSS dari tabel 9, dapat diketahui bahwa semua pernyataan untuk variabel Komitmen Organisasi, Kompetensi Auditor dan Kinerja auditor diatas adalah valid. Dikatakan valid karena Pearson Corelation tiap pernyataan lebih besar dari $r$ tabel yang terdapat pada lampiran yaitu $\mathbf{0 , 2 8 8}$ atau $\mathbf{r}_{\text {hitung }}>\mathbf{r}_{\text {tabel}}$.

Rumus Uji Reliabilitas: $\quad r_{11 \frac{2 \cdot r_{b}}{1+r_{b}}}$

Tabel 10. Tabel Uji Reliabilitas

\begin{tabular}{|r|r|}
\hline Cronbach's Alpha & N of Items \\
\hline, 903 & \\
\hline
\end{tabular}

Berdasarkan hasil perhitungan dengan program SPSS dari tabel 10, dapat diketahui Bahwa semua nilai reliabilitas 0,903 adalah reliabel. Dikatakan reliabel karena Cronbach's Alpha lebih besar dari pada 0,800.

\section{Uji Hipotesis}

\section{a. Uji Simultan (uji F)}

Uji F digunakan untuk mengetahui ada tidaknya pengaruh secara bersamasama variabel bebas terhadap variabel terikat, yaitu dengan membandingkan antara $F_{\text {hitung }}$ dengan $F_{\text {tabel. }}$ Apabila $F_{\text {hitung }}>F_{\text {tabel }}$ maka $H_{0}$ ditolak dan $H_{a}$ diterima. Tapi bila $F_{\text {hitung }}<F_{\text {tabel }}$ maka $H_{0}$ diterima dan $H_{a}$ ditolak. 
Tabel 11. Uji Hipotesis Simultan Antara Variabel Komitmen Organisasi $\left(X_{1}\right)$ dan Variabel Kompetensi Auditor $\left(\mathbf{X}_{2}\right)$ Terhadap Variabel Kinerja Auditor.

\begin{tabular}{|c|c|c|c|}
\hline $\begin{array}{c}\text { Variabel yang } \\
\text { dihipotesis }\end{array}$ & $\mathbf{F}_{\text {hitung }}$ & $\mathbf{F}_{\text {tabel }}$ & Signifikan \\
\hline $\mathbf{X}_{1}$ dan $\mathbf{X}_{2} \rightarrow \mathbf{Y}$ & $\mathbf{4 5 , 5 1 9}$ & $\mathbf{4 , 0 7}$ & $\mathbf{0 , 0 0 0}$ \\
\hline
\end{tabular}

Berdasarkan hasil perhitungan dengan program SPSS diperoleh $\mathbf{F}_{\text {hitung }}$ sebesar 45,519 sedangkan nilai $F_{\text {tabel }}$ diperoleh sebesar 4,07. Dalam hal ini, $F_{\text {hitung }}>F_{\text {tabel }}$ maka $\mathbf{H}_{0}$ ditolak dan $\mathrm{H}_{\mathrm{a}}$ diterima. Yang berarti dapat ditarik kesimpulan bahwa komitmen organisasi dan kompetensi auditor mempunyai pengaruh yang signifikan terhadap kinerja auditor.

\section{b. Uji Parsial}

Uji t digunakan untuk mengetahui ada tidaknya pengaruh masing-masing variabel terikat terhadap variabel bebas yaitu antara komitmen organisasi terhadap kinerja auditor dan kompetensi auditor terhadap kinerja auditor yaitu dengan membandingkan antara $t_{\text {hitung }}$ dengan $t_{\text {tabel }}$. Apabila $t_{\text {hitung }}>t_{\text {tabel }}$ maka $H_{0}$ ditolak dan $H_{a}$ diterima. Tapi bila $t_{\text {hitung }}<t_{\text {tabel }}$ maka $H_{0}$ diterima dan $H_{a}$ ditolak.

Tabel 12. Uji Hipotesis Parsial Antara Variabel Komitmen Organisasi $\left(X_{1}\right)$ Terhadap Kinerja Auditor (Y) dan Variabel Kompetensi Auditor $\left(\mathbf{X}_{2}\right)$ Terhadap Variabel Kinerja Auditor (Y).

\begin{tabular}{|c|c|c|c|}
\hline $\begin{array}{c}\text { Variabel yang } \\
\text { dihipotesis }\end{array}$ & $\mathbf{t}_{\text {hitung }}$ & $\mathbf{t}_{\text {tabel }}$ & Signifikan \\
\hline $\mathbf{X}_{1} \rightarrow \mathbf{Y}$ & $\mathbf{2 , 0 2 5}$ & $\mathbf{1 , 6 8 1}$ & $\mathbf{0 , 0 4 9}$ \\
\hline $\mathbf{X}_{2} \rightarrow \mathbf{Y}$ & $\mathbf{2 , 2 2 4}$ & $\mathbf{1 , 6 8 1}$ & $\mathbf{0 , 0 3 2}$ \\
\hline
\end{tabular}

a. Pengujian ( $\mathbf{t}_{\text {hitung }}$ ) koefisien komitmen organisasi

Berdasarkan pengujian SPSS, nilai $t_{\text {hitung }}$ untuk komitmen organisasi adalah 2,025 dan nilai $t_{\text {tabel }}$ diperoleh 1,681. Apabila $t_{\text {hitung }}>t_{\text {tabel }}$ maka $H_{0}$ ditolak dan $H_{a}$ diterima. Sedangkan bila $t_{\text {hitung }}<t_{\text {tabel }}$ maka $H_{0}$ diterima dan $H_{a}$ ditolak. Dan dari hasil perbandingan antara $t_{\text {hitung }}(2,025)$ dan $t_{\text {tabel }}(1,681)$ ternyata $t_{\text {hitung }}>t_{\text {tabel }}$ sehingga dapat disimpulkan bahwa komitmen organisasi mempunyai pengaruh yang signifikan terhadap kinerja auditor.

b. Pengujian ( $\mathbf{t}_{\text {hitung }}$ ) koefisien kompetensi auditor

Berdasarkan pengujian SPSS, nilai $t_{\text {hitung }}$ untuk kompetensi auditor adalah 2,224 dan nilai $t_{\text {tabel }}$ diperoleh 1,681. Apabila $t_{\text {hitung }}>t_{\text {tabel }}$ maka $H_{0}$ ditolak dan $\mathbf{H}_{a}$ diterima. Sedangkan bila $t_{\text {hitung }}<t_{\text {tabel }}$ maka $H_{0}$ diterima dan $H_{a}$ ditolak. Dan dari hasil perbandingan antara $t_{\text {hitung }}(2,224)$ dan $t_{\text {tabel }}(1,681)$ ternyata $t_{\text {hitung }}>t_{\text {tabel }}$ sehingga dapat disimpulkan bahwa kompetensi auditor mempunyai pengaruh yang signifikan terhadap kinerja auditor. 


\section{KESIMPULAN DAN SARAN}

\subsection{Kesimpulan}

Setelah melakukan penelitian dan pengolahan data, maka penulis memberi kesimpulan bahwa komitmen organisasi dan kompetensi auditor memiliki pengaruh terhadap kinerja auditor, hai ini didukung oleh :

a. Berdasarkan hasil analisis deskripsi frekuensi jumlah responden tentang komitmen organisasi dan kompetensi auditor cukup baik dan kinerja yang dimiliki kurang baik.

b. Berdasarkan hasil analisis deskripsi score jawaban responden tentang komitmen organisasi dan kompetensi auditor cukup baik artinya auditor memiliki komitmen organisasi yang cukup baik dan kompetensi auditor yang cukup baik sehingga membuat kinerja yang dihasilkan oleh auditor menjadi kurang baik.

c. Berdasarkan analisis regresi linier berganda menunjukkan tanda (+). Hal ini berarti persamaan regresi linier berganda memiliki hubungan yang searah yaitu peningkatan variabel $(X)$ akan menyebabkan peningkatan variabel $(Y)$.

d. Berdasarkan hasil uji validitas menunjukkan $\mathbf{r}_{\text {hitung }}>\mathbf{r}_{\text {tabel. }}$ Dimana $\mathbf{r}_{\text {tabel }} \mathbf{0 , 2 8 8}$. Maka data tersebut adalah valid.

e. Berdasarkan hasil uji reliabilitas diperoleh Cronbach's Alpha 0,903 > 0,800. Yang berarti data tersebut adalah reliabel.

f. Berdasarkan pengujian hipotesis secara simultan $F_{\text {hitung }}(45,519)>F_{\text {tabel }}(4,07)$ maka $H_{0}$ ditolak dan $H_{a}$ diterima. Yang berarti semua variabel independen yaitu $\left(X_{1}\right.$ dan $\mathrm{X}_{2}$ ) berpengaruh signifikan terhadap variabel dependen $(\mathrm{Y})$.

g. Berdasarkan pengujian hipotesis secara parsial pada variabel $X 1 t_{\text {hitung }}(2,025)>t_{\text {tabel }}$ (1,618) maka $H_{0}$ ditolak dan $H_{a}$ diterima, yang berarti variabel $X_{1}$ Berpengaruh signifikan terhadap $Y$, dan pada variabel $X_{2} t_{\text {hitung }}(2,224)>t_{\text {tabel }}(1,618)$ maka $H_{0}$ ditolak dan $\mathrm{H}_{\mathrm{a}}$ diterima, yang berarti $\mathrm{X}_{2}$ berpengaruh signifikan terhadap $\mathrm{Y}$.

\subsection{Saran}

a. Perlu ditingkatkannya rasa cinta terhadap organisasi berupa mematuhi peraturan pimpinan, melakukan pekerjaan secara maksimal demi organisasi, dan rela berkorban demi organisasi, bahkan dalam keadaan yang sangat mendesak auditor harus selalu ada untuk organisasi.

b. Perlu ditingkatkannya kompetensi auditor terutama dalam bekerja. Pengalaman dan pengetahuan auditor harus ditingkatkan dengan cara respon terhadap senior dilingkungan auditor dan auditor-auditor lain diluar organisasi. Dan mengikuti seminar-seminar yang berhubungan dengan pekerjaan auditor agar menambah pengetahuan dan pengalaman bagi auditor. Karena auditor yang kompeten sangat dibutuhkan didalam organisasi.

c. Yang paling penting adalah harus meningkatkan kinerja auditor yaitu didalam bekerjasama didalam tim dalam mengaudit berupa menghargai pendapat rekan satu tim, tidak boleh egois, harus bertanggung jawab, jujur, taat dengan peraturan organisasi, dan setia terhadap organisasi.

d. Pimpinan Kantor Inspektorat Provinsi Lampung melalui Kasub. Kepegawaian harus lebih tegas memperhatikan kinerja dari para auditor dan auditor perlu mengikuti pelatihan-pelatihan dan seminar-seminar untuk menambah pengetahuan dan pengalaman yang berhubungan dengan pekerjaan auditor. 


\section{DAFTAR PUSTAKA}

Arens \& Loebbecke. 1996. Auditing. Penerbit Salemba Empat. PT. Ikrar Mandiriabadi. Jakarta.

Arikunto, Suharsimi. 1998. Prosedur Penelitian. Suatu Pendekatan Praktik. Penerbit Rineka Cipta. Jakarta.

Herliansyah, Yudhi. 2008. Metodelogi Penelitian. Universitas Mercubuana. Jakarta.

Kusharyanti. 2003. Temuan Penelitian Mengenai Kualitas Audit dan Kemungkinan Topik Penelitian Dimasa Datang. Jurnal Akuntansi dan Manajemen. Desember.

Mayangsari. 2003. Pengaruh Keahlian dan Independensi Terhadap Pendapat Audit. Jurnal Riset Akuntansi Indonesia. Januari.

Lanstanti, Sri. 2005. Tinjauan Terhadap Kompetensi dan Independensi Akuntan Publik. Media Riset Akuntansi Auditing dan Informasi. April.

Sugiyono. 2005. Metode Penelitian Bisnis, Penerbit CV Alfabeta. Bandung.

Sugiyono. 2007. Metode Penelitian Administrasi. Penerbit CV Alfabeta. Bandung.

Sumber-sumber lain :

Parmenpan No. PER/05/M.PAN/03/2008 Tentang Standar Uudit APIP

Parmenpan No. PER/04/M.PAN/03/2008 Tentang Kode Etik APIP

http://id.wikipedia.org/wiki/Komitmen_organisasi.pada 04 desember 2011

http://id.wikipedia.org/wiki/Kinerja. pada 04 desember 2011

http://www.docstoc.com/docs/26564667/Pengertian-Kompetensi. pada 04 desember 2011

http://www.scribd.com/doc/51208226/23/Audit-Internal-Pemerintah-Daerah. pada 03 april 2012 